\title{
ARCHIVE
}

Recognised as the intellectual patron of the conservative ideological current, Viacheslav Lypyns'kyi (1882-1931) ranks amongst the most interesting Ukrainian historians and political thinkers. A Pole by birth (born Wactaw Lipinski), and a Roman Catholic subject of the Russian Empire, he assumed Ukrainian national identity during his school years spent in Zhytomyr and Kiev. He completed his tertiary studies at the Jagiellonian University in 1908. In his historical and journalistic pieces published in Polish and Ukrainian during the few subsequent years, Lypyns'kyi elaborated an innovative interpretation of the 1648 Khmelnytsky Insurrection and a related sociological theory of nation. ${ }^{1}$ In the course of the First World War, following a short frontline service (as a Russian reserve officer), he joined the attempts to create a Ukrainian statehood, offering his support to the rule of Hetman Pavlo Skoropads'kyi. After the Bolsheviks prevailed, Lypyns'kyi spent the rest of his life as an émigré in Vienna, publishing profusely and contributing to the organisation of Ukrainian conservative and monarchical groups or factions.

Lypyns'kyi's ideas stood out against the then-dominant interpretations of Ukrainian history, which linked Ukrainianness with the popular element and with democratism. In contrast to the great historian statesman Mykhailo Hrushevs'kyi, Lypyns'kyi identified in his country's past a detrimental deviation from the European standard, which was made evident through the loss of native knightly and, subsequently, nobility elites. Khmelnytsky's revolt was, in his opinion, an attempt at resuming the appropriate developmental path of the national idea. Lypyns'kyi demonstrated that the Polish-Ukrainian conflict in the seventeenth century was not a class conflict but a national clash that affected all the social strata. The functions of importance in Khmelnytsky's camp were held by Ruthenian noblemen, whose purpose was to establish a country of their own, as the only path to national sovereignty. Completion of the nation-forming process

${ }^{1}$ Lypyns'kyi's influence on Ukrainian historiography is discussed in Omeljan Pritsak, 'V. Lypyns'kyj's Place in Ukrainian Intellectual History,' Harvard Ukrainian Studies, ix, 3-4 (1985), 245-62. The essay was contained in a special monographic issue of HUS, devoted to Lypyns'kyi (The Political and Social Ideas of Vjačeslav Lypyns'kyj), whereon V. Lypyns'ky's essay published below is based. Of Polish authors, Tomasz Stryjek deals with Lypyns'ky in his excellent study on the Ukrainian national idea in the interwar period (Ukrainska idea narodowa okresu międzywojennego. Analiza wybranych koncepcji, Wrocław, 2000, 61-109). 
would have called for a similar act of emancipation from the Russian dominance and, above all, a change in Ukraine's social structure. To meet the latter goal, the elites had to be retrieved, the historian argued. The measures to fulfil the task were described by Lypyns'kyi in much more a generalised manner, compared to his diagnoses of the earlier defeats or setbacks. Putting it in simplified terms, he foresaw a reintroduction of elites through enlargement of the landowner stratum by way of a limited agricultural reform. According to his concept, the Ukrainian nobility should have realised their obligations toward their native land (in some measure, as he himself had done some time earlier on). The inflow of new landed property owners, of affluent peasantry background, was expected to ensure this most active social class strength and vitality.

Lypyns'kyi was, in a sense, a mouthpiece of the ideas appearing in the nineteenth and twentieth century almost all across East Central Europe. Wherever the higher social classes were separated from the lower ones by language, apart from wealth and culture, 'national wakeners' appeared who deliberately assumed the identities of the peoples that formulated their political programmes. Lypyns'kyi's conservative views seem quite interesting in this context: this author consistently (also in the article whose English translation is published below) criticised the exalted idealisation of the peasantry among activists of the elitists background. His view of the 'Provencalism', the term he used to describe the cultivation of cultural, and not political, sense of national identity, was no less critical. The significance he ascribed to state and complete social structure has led him to rejection of ethnic nationalism. Ukraine, he believed, had become a colony, and would remain one until, and unless, at least a part of the colonial elite assumed the stance of self-reliance, in statehood terms.

In his appraisal of the importance of this man to the development of Ukrainian national movement, Dmytro Doroshenko, an illustrious Ukrainian historian and friend of Lypyns'kyi's, referred "not exactly to his plans or practical formulas but basically, to the new principles upon which he has developed his conception of Ukrainian statehood; the new prospects he has opened to the Ukrainian thought; and, in particular, the high elevation of the spirit that is, one and only, capable of kindling the hearts, filling the exhausted human souls with hope, and stimulating a new grapple for one's ideals". ${ }^{2}$ Our Editorial Board, however, took into account somewhat

2 Dymitr Doroszenko [Dmytro Doroshenko], 'Wacław Lipiński. Kilka wspomnień i uwag,' Harvard Ukrainian Studies ix, 3-4 (1985), 466-76; quote 476. 
different premises in making their choice for this issue's Archive section. In our opinion The tragedy of the Ukrainian Sancho Panza is, above all, an immensely interesting contribution to the discussion on the peculiar roads of historical development. Although the essay shows its author's own view of the history of Ukraine, in the form of a literary metaphor, the problems it raises are the crucial and critical ones to the history of East Central Europe - with the singularities of local social structure and nation-formation process standing out. For scholars embarking on the subject-matter of regional 'multiple Sonderwegs' Lypyns'kyi is a grateful topic in itself - and an elder professional colleague.

The present translation has been based on the Ukrainian text as published in a 1985 Harvard Ukrainian Studies issue, dedicated to the output of Viacheslav Lypyns'kyi. The Author's notes appearing at the bottom of the pages are not footnotes, but marginal glasses that are written alongside the main body of the original text.

Maciej Górny 


\section{THE TRAGEDY OF THE UKRAINIAN SANCHO PANZA (FROM AN ÉMIGRÉ'S NOTEBOOK)}

Cervantes's work of genius is perennially up-to-date. Its characters are immortal, since over the centuries they have repeatedly been reviving in every new generation of European nations. Don Quixote and Sancho Panza go side by side across the history of Europe: the inseparably interconnected symbols of old European culture - varying in forms but essentially homogeneous.

Idealism and realism. Tradition and progress. The past and the future are interconnected. Deep belief in one's own understanding of life, as shaped by the generations, and practical everyday use of the real forms of life: these are the two sides of what is named culture, and they are constitutive to culture's coherence while ensuring its lastingness, strength, and evolutionism, even under revolutionary circumstances. This is the Europe in which the pragmatically inclined Sancho Panza implements the ideas of Don Quixote, the romantic. The Europe which is entering the new era with monuments of the past centuries preserved, with piously preserved creations of human spirit, rather than with the tabula rasa of a steppe covered with ruins and smouldering fires...

The old cultural strata die back. New ones, with the strength of youth, pierce through to the surface, and take over the culture created by the old strata.

Don Quixote with his old rust-covered armour, with his convincement, inherited from his ancestors, that he has sprouted from the past, in his entirety, with his holistic, finely elaborated comprehension of the surrounding world. His belief is the traditional belief of his ancestors in the worthiness and beauty of life. He sets about making his life path with the single objective in mind: to save the belief, to save the knightly tradition, save the culture, save the experience of the 
past generations and pass this most valuable treasure over to Sancho Panza, his fellow-traveller.

Sancho Panza has nothing behind him. He wholly inheres in the future. He is delighted with the future journey, rather than the destination of this journey. He would not take his armour with him, nor the emblem of his dreams: the pennon of his lady. He is supposed to set off not because this is what his ancestors had done; the reason is, he is pushed to make his journey by his own abundant force that called for discharge.

Here they are: an idealist and a realist, abreast, on the same path of life. Sancho laughs dearly when Don Quixote perceives the windmills as a knightly army. He only shrugs his shoulders, wondering how could Don Quixote regard Dulcinea, an old and ugly woman, as a belle, and make her his ladylove.

And yet he follows Don Quixote. For Don Quixote's images prettify his tough road. For, how uninspiring this road would have been if not for Don Quixote's legends transforming the insensitive reality into living images, stunning with diverse colours and splendid faraway prospects. For, how primitive and poor Sancho Panza's life would have been, had Don Quixote not enriched it with everything his ancestors had already been through; had he not taught Sancho their experience; had he not communicated to him the methods of responding to life that are constitutive of Don Quixote: the culture achieved by bygone generations.

And finally, Sancho Panza stops poking fun at Don Quixote. He has been imbued with the dying knight's deep faith, dons an armour himself, turns into a Don Quixote, and becomes followed by a new Sancho Panza.

And Sancho Panza believed in Don Quixote because the European Don Quixote not once has taken fright in Sancho's primitive chortle; and, hearing the chortle, never did he lose self-confidence and the commandments transferred to him through the forefathers' experience.

"You shall grow up, wise up, and start believing that the only value in life is the image we can develop for ourselves about it, rather than the fractions of life you can watch with your limited sight": so thought Don Quixote, even when he was abandoned in the midst of the desert, and when this picture eminently gratified Sancho Panza. Don Quixote's unshakeable faith and sound culture fascinated Sancho. He [Don Quixote] won because he would never count on Sancho Panza or request his advice, but went his own way: for he was Don Quixote, 
a knightly descendant; because, influenced by culture, nothing remained in him of his ancestor Sancho Panza anymore. The European Don Quixote is no democrat. He cannot exist without a Sancho Panza, as he can see himself continued in him: a Don Quixote-to-be.

The existence of modern European nation would be unimaginable without Don Quixote. If a nation, according to Sancho Panza's realistic views, were a group of people sharing a language, then, in the name of realistic interests, and in the name of those people's practicalism, it would be better to alter the language and begin speaking in the way dictated by the real interests of the community. And this is what the Sancho Panzas of all the nations without their own Don Quixotes did. ${ }^{1}$ Only at the point that Don Quixote has turned the vulgar, crude, and most ordinary Dulcinea into the lady of his heart and honour; when he fecundated the real fact of human life with the spirit of an idea; when the mechanical, ethnographic collectivity grew selfassertive, and conceived an affection for their ideological image, their own tradition, and their culture once the primitive Sancho Panzas believed in the national Don Quixotes, and began laying down their lives for the idea of their nations - only then did the European nations emerge, those complex spiritual collectivities which no new Sancho Panza, using any of his realistic methods, could possibly understand. ${ }^{2}$

Opinions can be heard now in the Ukrainian literature that Ukraine is a country of the Asian East; that we have a lot in common with China, where only peasants and mandarin intellectuals dwell; that there resides strength in the East, and that we had better turn our back on the decayed Europe. One could even believe in all this, had all those things-so-nice been written elsewhere than in Vienna. ${ }^{3}$ As long, however, as Ukrainian intellectuals were fleeing from the Bolshevik onslaught - just like their forefathers from the Halych State time: West-ward, rather than to a 'spiritually close' China - it has remained

${ }^{1}$ The tasks of national idealism - creation of the national legend - always, and everywhere, fall on the social strata which represent the national tradition. The successors of the stratum that has created the glory of nations are called to renew the tradition [Author's note].

${ }^{2}$ Disappointed with Sancho, Don Quixote joins the service of alien Sancho Panzas [Author's note].

${ }^{3}$ Vienna was one of the main centers of Ukrainian political emigration in the interwar period. 
true that Ukraine is a Western-culture country, and we are bound by the main lines of development set by this culture.

Where is our Don Quixote, then, and our Sancho Panza, without whose existence culturally Western nations are inconceivable?

When in the spring of 1648, Bohdan Khmelnytsky stood out against the whole might of the Polish Commonwealth, departing from the steppe-covered Ukraine, armed solely with a bare faith that he could extricate the entire Ruthenian nation from the Lakhs' [Polish] bondage, then the Ukrainian Sancho Panza, who saw Khmelnytsky's real forces, composed of a few hundred people, was all in stitches while watching his Don Quixote then. ${ }^{4}$ But the Great Bohdan took no fright at the Barabashian ${ }^{5}$ croak, and marched on together with his boys straight to the target, never counting on his Sancho; never asking Sancho what he might be thinking - and infected with his faith millions of Ukrainian Sancho Panzas; and snatch he did the Cossack Ukraine from the Polish regime.

Ukraine buried her last Don Quixote in the year 1657. His life was too short. All his associates were killed to a man, and the last Ukrainian Don Quixote missed the opportunity to transfer upon Sancho Panza his characteristics, or his character. ${ }^{6}$ When the last Ukrainian Don Quixote died, Sancho Panza did not believe in his idea and resumed his realistic route: the 'practicalist' path. He set about trying to build a Ukraine with use of realistic and practical methods, and what real force could be used as a support to this end. Instead of creating a life inside himself, he started looking closer at life and, having been lost on a straight way of practicalism, he has forfeited his route: he hesitated along with Vyhovsky ${ }^{7}$, and with Mazepa ${ }^{8}$; he shared the emigration trip with

${ }^{4}$ As long as the Ukrainian Don Quixote lived, the Ukrainian nation was alive. Sviatoslav was a Don Quixote; he would never ask the nation what form the rule should assume, and how should he tackle the issue [Author's note].

${ }^{5}$ Ivan Barabash († 1648), Cossack leader loyal to the Polish king. In May 1648, Barabash was executed by the insurgents.

${ }^{6}$ Those who came after him had no faith anymore. They were hesitating, fearing ridicule, fearing great gesture [Author's note].

${ }^{7}$ Ivan Vyhovsky ( $†$ 1664), Cossack hetman and successor to Khmelnytsky.

${ }^{8}$ Ivan Mazepa (1639-1709), Cossack hetman. In the Great Northern War Mazepa allied with Sweden and the Polish king Stanisław Leszczyński against his former patron tsar Peter I. 
Orlyk ${ }^{9}$; he was laid to rest in the tomb alongside Kalnyshevsky. ${ }^{10}$ No more of the Ukrainian Don Quixote meant no more of the Ukrainian nation. ${ }^{11}$ But, there existed a sound, mechanist, and real human collectivity. This community still produced the raw material to make Don Quixotes and Sancho Panzas of. Without the Ukrainian faith and Ukrainian culture, though, our Don Quixotes converted to alien faiths and became foreign Don Quixotes. They would fall for a Poland 'from Sea to Sea', and contribute to the power and might of the Great Russian Empire. Only corporal Don Quixotes stayed by Ukraine's side: those with no confidence in themselves, in their own culture and destiny. Our Don Quixote turned into a humbling courtier who initiated the epoch of, as it is called, revival of the Ukrainian nation.

Meanwhile, the nobility and the Cossacks had been replaced by peasantry, the newly-emerged stratum. A new Ukrainian Sancho Panza was born, who was on the lookout for his own Don Quixote: for the cultural strata that would attract him, lead him with their experience and culture. ${ }^{12}$ Instead, however, of his own Don Quixote, Sancho spotted a Russian and a Polish Don Quixote. And, like any Sancho Panza, he got ashamed of his Lesser-Russian root $^{13}$; he engaged as a scribe in the town, at a printing-house, as a coachman, as some petty official, and moved along the path indicated by the Don QuixoteRussified, or perhaps, began switching to Latin, as suggested by the Don Quixote-Polonised.

Yet, as any Sancho Panza would do, our one loves 'beauty and strength'. He would not be satisfied with strength alone; and, he would not sense his own beauty in murdering his own language and in wearing a Polish square-topped cap. And, since the traces of the old Ukrainian Don Quixote still persisted in Ukraine, it was following these traces, amidst the Cossack graves in the steppe,

${ }^{9}$ Pylyp Orlyk (1672-1742), Cossack hetman in Ottoman and Moldavian exile after Mazepa's death.

${ }^{10}$ Petro Kalnyshevsky ( $\dagger 1803$ ), the last Zaporozhian ataman, participant of the Russo-Turkish war 1768-1774.

${ }^{11}$ Abandoned by him, Sancho Panza [...?] gave his last, and he is frightened to death [Author's note].

${ }^{12}$ And so he grew, young, strong, and beautiful - and life surged in him with the force of our fertile land, our sound nature [Author's note].

${ }^{13}$ The tradition-observing families: the noble and the clergyman's one [Author's note]. 
that Sancho Panza started looking around for his own Don Quixote - and there he came across a humiliating Ukrainian courtier and an Orthodox-pope's son. ${ }^{14}$

The very first meeting turned out not-too-pleasant for our Sancho. ${ }^{15}$ A realist, he spotted in front of himself the very same Don Quixote as those others; whilst they were self-confident, and did all their own way, this one dressed up in a frock and requested Sancho for condonation: as his background was a squalid lordly house; as his ancestors permanently wronged Sancho Panza - with him having been the one to abase himself, pull the wool from his eyes; now, he was going to request Sancho's forgiving, with the whole of his life. ${ }^{16}$ What is more, Sancho expected to receive from Don Quixote the leadership and a teaching, but what he heard was that in Ukraine he, Sancho Panza, was the only one to know any and all ways, and that Don Quixote, the loyal courtier, was ready to follow Sancho wherever he would be led by him.

Our Sancho Panza did break [?] at once, on that very first meeting, with the culture of 'lies', and he became helpless and nervous; he felt that someone was laying a deadweight task on his shoulders but, having no choice, our Sancho Panza had to hit his tough road without having in front of him (contrary to the other, more fortunate nations) the thoroughly self-confident Don Quixote, armed with experience and culture; instead, he trailed the persistently crying and snotty-nosed courtier and the lowly pope's son.

As they walked on, the following conversation ensued between the two guys:

"You tell me, Don Quixote", Sancho Panza asked, "why are we not like those others. Behold, everyone has their state, is proud of his language, and us? There is no state that we have, and ashamed we are of our speech."

${ }^{14}$ The humble courtier and the idealised barefooted-guy are the two cultural types that have been made part of our life through the Muscovite element [Author's note].

${ }^{15}$ Because he only values one thing in the world - that is, force; there is nothing he hates more than frailty [Author's note].

16 "You must be a Ukrainian, if one half of you is Polish-noble, and the other, Muscovite-tsarist?" "And you, one amongst whom shall you be: the moderate, or the sincere ones?" "None of those, but such ones that you need, my dear Sancho Panza!" [Author's note]. 
"Because we", Don Quixote replied, "are not capable of living a state-oriented life. Our language, besides, is only suitable for singing songs, and for pursuing the domestic culture. Therefore, what we need is speaking Russian amongst people, for Russian is the state language." 17

But the reply did not quite please Sancho, and so he said:

"So, who is guilty of this happening so?"

"It is my ancestors that are guilty", Don Quixote replied. "Stupid they were, and flaunting; they did not listen to you, Sancho Panza, and thus they had forfeited the state. Now, however, we are following you, and whatever you say, shall be obeyed.

"Well then, is this to say that my ancestors were willing to build the state, whereas yours were obstructing them?"

"Naturally!", Don Quixote replied, scared. "Your ancestors were making terror against their prince, for instance; then, they were killing their hetmans, and invoked the Muscovite voivodes; in a word, they were murdering my forefathers as they possibly could; but you, Sancho Panza, have mercy upon me, for I, I swear, want only what you want, and I shall follow your lead, even if you lead me where I would rather not go."18

Sancho spat crossly, and decided never again to talk to humble courtiers or self-effacing pope's sons about the past, and to make rollups of their multivolume stories. But, since the real life posed its harsh demands to the poor Sancho Panza, then he, powerless, listened to the slimy fibs of his indign Don Quixote and, knowledgeable of nothing else, believed in a non-statehood status of the Ukrainian nation - and decided he would only demand autonomy for himself.

"How should I attain the autonomy, then?"

17 "The nation alone shall attain Ukraine", the Ukrainian Don Quixote said; but Sancho Panza, one of whose forefathers had served as a police constable, received the words uttered by Don Quixote rather reservedly [Author's note].

${ }^{18}$ Sancho found it hard to believe that his forefathers were stupid enough to smash their own country, and he could feel with his pure heart that the Ukrainian Sancho Panza has ever walked his way around the world because there once was King Daniel, rather than Tatar people.

Sancho very much wanted to become a master himself, but the lowly courtier did not believe in the real Don Quixote; to be a master would mean never to beg, never to prostrate oneself, have a deep faith and respect yourself as well as the others ... [?] [Author's note]. 
"Through bargaining with the Russian oppositional circles", the lowly courtier and the humble pope's son timidly prompted.

Sancho Panza angered at that point, though. With his practical mind, he knew that when one quarrels with his neighbour over the balk, it is not the neighbour's son's or brother's help that he would call. And, he completely ceased trusting Don Quixote, who toddled behind him.

Since, however, no Sancho Panza can possibly jump up higher than his Don Quixote, our Sancho turned his sight to where Don Quixote pointed. And he went to take a look at the Russian oppositional circles, and could see that a new faith was spreading there: the cult of tramp. A belief that very much tickled the fancy of our orphan Sancho Panza. No filthy Don Quixote was needed anymore. He, Sancho Panza, must at times find his own way; he would spearhead everybody, turning into Don Quixote himself. And he abandoned his Don Quixote; and, following the example of the Russian neighbours, our Sancho Panza went about barefooting.

The more he barefooted around, the more he cared about his new faith. His teacher, a Russian teacher, told him that the cult of barefootedness was spreading all over Europe, and that they call it there a 'liberation of the proletariat'. Since our Sancho Panza never visited Europe and knew none of the European languages, he believed his Russian teacher's word, unaware, poor thing, that European proletariat had their deep culture, that they had nothing to do with the Russian barefooted-guys; that they were led by their own Don Quixotes, themselves educated into a long tradition and strong with their faith. The barefooted-guy cult changed everything for our Sancho Panza. He donned the rubbers and a red shirt. He started cursing foully, playing the accordion, and waiting till the appropriate time comes. ${ }^{19}$ But even then he would not do without an influence of his own Don Quixote. Sancho Panza learned from him how to write, as he believed that the whole wisdom lies in literature, and set about enunciating his barefootedness ideology in multivolume works. ${ }^{20}$ And thus the beauty and the strength with which our Sancho Panza began climbing up the steep rungs of his life were mutilated completely.

${ }^{19}$ And thought Sancho Panza that muddling in one's own self, spitting on oneself were, precisely, the hallmarks of a higher culture [Author's note].

${ }^{20}$ The more the Ukrainian Don Quixote cajoled Sancho, the more tremendous was Sancho finding his images as blazoned in his works, and all the more did they resemble some apocalyptic beasts [Author's note]. 
The Ukrainian humble courtier and modest pope's son took fright about the fate of their Sancho Panza. They beheld that he on whom they had put their great expectations upon fled somewhere from them; and our scrawny Don Quixote started waiting on Sancho hand and foot.

He took over Sancho's ideology (the strikes at his father's) and, even if making himself uncomfortable, he wrote commending reviews, printed and published works. He took Sancho abroad, and founded the anti-Don Quixote party together with him; he bent over backwards to convert in the way Sancho would find appealing. But this only aroused increasing disdain in Sancho Panza. ${ }^{21}$

"Now, write, Don Quixote, your last word. Now, die; the sins of your youth are taking revenge upon you; the barefooted-guy affairs comprehend will you not": such was the advice Sancho Panza gave his Don Quixote. He however did not even think, poor, that he was incapable of getting rid of Don Quixote: for Sancho Panza and Don Quixote are twin brothers, and there is no force able to separate them.

But Don Quixote would not stop. In order to get closer to his Sancho, he married one of his sisters, invited him to his home, fed him, tended him, drove away the flies from Sancho when asleep after dinner; he would jump through the window so as not to use the creaking doors and irritate Sancho's nerves; all in vain, though.

"You think you might beguile me, Don Quixote, you soft-headed man? ${ }^{22}$ I know my sister better than you do; it is not love but money that she had married you for, and now, you are both going to cheat me. No way!"

And showed Sancho Panza his 'Young Blood' to the poor humble courtier...

Without his Don Quixote, without belief in the nation, without belief in the national idea, the hour came upon our Sancho Panza when the nation should have uttered their word. ${ }^{23}$ And at that

${ }^{21} \mathrm{He}$, indeed, would have done whatever. He would at times quit politics, and get onto culture. He would write, for Sancho, about the Space, or hygiene, and he unceasingly tried to amuse him. But when this failed, he resolved to play up to Sancho through ideology [Author's note].

${ }^{22}$ What you simply are is a petty-bourgeois aspic-in-the-grass, and sleazy coaxer [Author's note].

${ }^{23}$ Without his Don Quixote, he had to get round to creating a life; to tilting at windmills [Author's note]. 
horrible hour, when not a single minute should have been wasted, together with the humble courtier and with the modest pope's son, Sancho Panza did walk the same route he has once made; and again, there was autonomy in this futility - nay, together with the Russian oppositional circles, and again did Don Quixote beg Sancho to show him the way, [...?] around him, collecting votes, paid court in all ways possible, singing all days long, not just hours. All that ended up in nothing, again. The outcome resembled the conception: Sancho Panza, namely, flung the miscreant Don Quixote out of the door, and went out to seek for his faith amongst the neighbours - the tramps, for he was not satisfied with his own faith, as Don Quixote, his own, had given him no such faith. ${ }^{24}$

And when the neighbours' daydreams came true, Sancho Panza went away to see his neighbour, hoping that freedom from all the Don Quixotes would finally set in, and the kingdom of Sancho Panzas would descend. But he was to come across a tragedy: he came over and saw that the neighbours there had a custom such that when the Russian Don Quixote wanted to appeal to his Sancho Panza, he would dress himself the barefooted-guy way. And the poor Sancho could see that instead of the goods the barefooted-guy neighbour had promised him, the only winning party was the own, national, Muscovite Don Quixote. Because, unaware of the history, and unaware of the tradition, which is more powerful than a theory, Sancho Panza would not know that there has prevailed amongst the neighbours an immemorial custom whereby Don Quixote the Muscovite, if he is willing to enrapture Sancho Panza, would dress himself up in the barefootedguy apparel, but underneath it there always beats the heart of the Muscovite Don Quixote. "-",Sancho Panza wrote, and he eventually emigrated - to where all the most leftist, most lowly courtiers and humble pope's sons had already landed.

${ }^{24}$ And the Ukrainian Don Quixote began asking even more dearly:

"There is so many books that I have wrote for you; I was teaching you throughout my life, after all - never knowing a youth, or experiencing a delight; for I was kept gaoled; and all that, for you, Sancho Panza! Oh, do have mercy upon me, me alone. And then shall I be a communist, and a social revolution shall I make. But do not you separate from me, please, like I should not like to be detached from you forever.

But Sancho Panza does not like being begged, and he drove the degenerated Don Quixote off from his land [Author's note]. 
There were two other moments occurring within the period. The old Ukrainian Don Quixote of the Hetmanate was reborn for a while; in the western borderland of Ukraine, where the cult of lowly courtier and idealised barefooted-guys had not reached, he created a Halych Army. And, they say, Sancho Panza caught his breath for the first time in his life when the Hetmanate emerged; it is also said that he slept a quiet sleep only when Halych Army soldiers were on sentry duty beside him. ${ }^{25}$

But Don Quixote ran short of powers. He is in fight again, and Sancho Panza's tragedy has begun again. He was expelled, just with a bag, and in his just indignation, fulminated he, with all his anger, against his Don Quixote: that he was too weak; that he was incapable of attracting him.

And, our Sancho will be harrowed until a Ukrainian Don Quixote appears. He will be roving amidst his real and practical combinations; until Don Quixote attracts him, with his own faith, into the universe of the Don Quixotean Spirit, not boring but delightsome with its images. It has not befallen a roughened, barefooted-guylike, self-slandering Ukrainian intellectual, with a lowly-courtier and modest-pope's-son background, to ravish Sancho Panza, who respects and loves beauty and strength only. Don Quixote's adamant trust in himself, in his own old armour, in his own old tradition, in his own old culture: this is what will put an end to Sancho Panza's tragedy. ${ }^{26}$

25 Once upon a time, the Ukrainian Don Quixote entered the Ukrainian Government, in order to support the Government and Sancho Panza, like a secret Nicodemus, when the barefooted-guy kingdom came.

"I did hope", wrote he, "to be employed, in some capacity, with the governmental party." (Nova Doba, 41) [Author's note]. [Nova Doba was political and cultural journal of the Ukrainian leftist exile group around Volodymyr Vynnychenko in Vienna. In 1920 Vynnychenko announced his desire to return to Soviet Ukraine. Yet, after couple of months there, he returned disillusioned to the emigration and Nova Doba acquired anti-Soviet line].

${ }^{26}$ Our Sancho Panza is a talented guy; the most talented, perhaps, amongst all his European brethren.

Our Sancho has missed one thing: the two-hundred years of the preceding culture. He would jump either not as high or as far, or too high or too far. He lacks the background of culture and tact [Author's note]. 
Don Quixote must become his usual self.

The boorishness of Don Quixote the democrat: this is the reason behind the Ukrainian Sancho Panza's tragedy. The Ukrainian Don Quixote will find his lost self-confidence, in the covenants of his forefathers he carries within him; and then shall Sancho Panza believe, and then will his horrific, bloody roving tragedy will come to an end.

trans. Tristan Korecki

The Lypyns'kyi article was published in Ukrainian as 'Трагедія українського Санчо Панча (Із записної книжки емігранта)', Harvard Ukrainian Studies 9, 3-4 (1985), 397-406. Used with permission. (C) 1987 by the President and Fellows of Harvard College. 